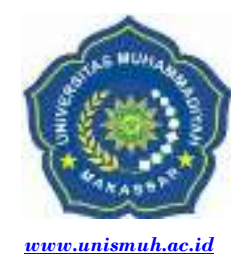

\title{
Nilai Sosial Ekonomi Sutera pada Masyarakat Pakkana Kabupaten Sengkang
}

\author{
Andi Nursida \\ Program Studi Pendidikan Sosiologi FKIP Universitas Muhammadiyah Makassar \\ andinursida@unismuh.ac.id
}

\begin{abstract}
The purpose of this study is to determine the socio-economic impact of the existence of silk weaving and professional composition in the community Pakkana Tanasitolo District Wajo District. The type of research uses qualitative research with data collection techniques using observation, interview and documentation. Data analysis techniques use qualitative decriptive with data reduction stages, data presentation, and conclusions. The results of this study indicate that (i) the impact of social values as everyday clothing and custom systems, as symbolic and distinctive identity for the Bugis community stratification system. (ii) Impact of economic value to supplement family income. The composition of Profession consists of farmers $17.92 \%$, civil servants $1.43 \%$, weaving traders $0.86 \%$, weaving businessman $0.75 \%$, weavers $17.13 \%$, police or army $0.35 \%$, driver $1.51 \%$ and others $66.16 \%$.

Keywords: Social Economics, Profession Composition
\end{abstract}

\begin{abstract}
Abstrak. Tujuan penelitian ini adalah untuk mengetahui dampak sosial ekonomi keberadaan tenun sutera dan komposisi profesi pada masyarakat Pakkana Kecamatan Tanasitolo Kabupaten Wajo. Jenis penelitian menggunakan penelitian kualitatif dengan teknik pengumpulan data menggunakan observasi, wawancara dan dokumentasi. Tehnik analisis data menggunakan dekriptif kualitatif dengan tahapan reduksi data, penyajian data, dan kesimpulan. Hasil penelitian ini menunjukkan bahwa (i) Dampak nilai social sebagai pakaian sehari-hari dan sistem adat, sebagai simbolis dan identitas ciri khas bagi sistem stratifikasi masyarakat Bugis. (ii) Dampak nilai ekonomi untuk menambah penghasilan keluarga. Komposisi Profesi terdiri dari petani $17,92 \%$, PNS 1,43\%, pedagang Tenun $0,86 \%$, pengusaha tenun $0,75 \%$, penenun $17,13 \%$, Polisi atau tentara $0,35 \%$, sopir $1,51 \%$ dan lain-lain $66.16 \%$.
\end{abstract}

Kata Kunci: Sosial Ekonomi, Komposisi Profesi 


\section{PENDAHULUAN}

Pembangunan sektor industri, terutama usaha kecil menengah (industri kecil) yang telah dilakukan pemerintah telah membawa awal era industrialisasi bagi bangsa dan negara Indonesia. Peranan industri kecil sangat penting dalam menciptakan kesempatan kerja sehingga dapat meningkatkan pendapatan masyarakat, dalam mewujudkan demokrasi ekonomi, yaitu dalam rangka peningkatan kemakmuran seluruh rakyat Indonesia secara adil, selaras dan merata. Industri kecil mempunyai misi menciptakan kesempatan berusaha dan kesempatan kerja dalam rangka meningkatkan pendapatan masyarakat, memperluas struktur usaha industri dan menumbuhkan budaya industri di kalangan masyarakat, dan membina kebedaan serta keberlansungan hidup industri yang berkaitan dengan nilai-nilai budaya bangsa. Sebagai salah satu bagian dari usaha kecil, industri tenun sutra di Kabupaten Wajo Provinsi Sulawesi Selatan merupakan sektor yang dominan di antara industri lainnya. Provinsi Sulawesi Selatan merupakan sentral industri sutera yang terbesar di Indonesia, sementara Kabupaten Wajo memiliki unit usaha tenun terbanyak di antara kabupaten lainnya yang berada di lingkup wilayah Sulawesi Selatan. Industri tersebut masih berupa usaha rumah tangga (home industry) yang banyak dikerjakan oleh ibu-ibu rumah tangga.

Bagi orang Wajo pada umumnya semangat berusaha, berbisnis, dan kerja sama serta berbagai aspek bernilai finansial lainnya, dapat dipastikan merupakan refleksi dari sistem ekonomi berdasarkan pandangan masyarakat Bugis Wajo. Dengan kata lain, sangat berpengaruh pandangan ini secara fundamental, juga sangat besar pengaruhnya terhadap berkembangnya jenis usaha seseorang. Katakanlah predikat usaha kain sutera bagi seseorang itu dipandang istimewa, otomatis dorongan untuk meraih prestise sosial itu akan mendorong seseorang bekerja giat dalam mengembangkan usaha dan reproduksi sebagai salah satu sumber pendapatan dalam kehidupan sehari-hari.
Kondisi inilah yang memberikan pilihan kepada pengusaha pengrajin pertenunan sutera untuk menggunakan benang sutera dari daerah, bahkan menggunakan benang sutera yang sudah ada walaupun dengan harga yang relatif mahal demi memenuhi tuntutan kualitas permintaan pasar yang ada. Industri pertenunan sutera merupakan kegiatan yang paling banyak digeluti oleh pelaku persuteraan di Kabupaten Wajo, di mana tenun sutra mempunyai nilai kegunaan yang dipadukan dengan nilai estetika budaya setempat.

Akan tetapi sepanjang perjalanan persuteraan di Kabupaten Wajo sudah mengalami tantangan dan masa-masa sulit sebagaimana sektor usaha yang lainnya. Sebagai masyarakat yang diterpah arus modernisasi maka banyak pula jenis profesi lain yang dimiliki masyarakatnya selain hanya penenun. Hal tersebut bisa mengikis budaya menenun sutera itu sendiri, namun karena prinsip yang selalu dipertahankan adalah profesionalisme dan integritas. Oleh karena itu, para pelaku persuteraan yang dibarengi dengan keuletan dan loyalitas mempertahankan profesinya dengan melakukan berbagai upaya pengembangan dan inovasi yang berguna menyebabkan mereka mampu eksis hingga saat sekarang ini. Dengan demikian, penenun sutera pada masyarakat Pakkana masih eksis memakai alat-alat tradisional dalam pembuatan sarung sutera dan masih dominan dalam satu keluarga para gadis/perempuan yang menjalankan peran sebagai karyawan di industri penenun sutera. Tenun sutera dalam kehidupan manusia menciptakan beragam kebutuhan, terkandung pula nilai sosial ekonomi, dengan beragamnya profesi yag digeluti masyarakat di era modern ini tetap membuat keberadaan kain sutera di Kecamatan Tanasitolo Kabupaten Wajo masih dijaga, dan dipelihara secara turun temurun, bahkan di antara mereka yang membuat kain sutera masih berusia gadis, orang tua dan lain sebagainya.

\section{METODE PENELITIAN}

Penelititan ini merupakan penelitian deskriptif kualitatif. Penelitian ini dilakukan pada 
masyarakat Bugis Sengkang yang lebih dikhususkan pada masyarakat Pakkana Kecamatan Tanasitolo Kabupaten Wajo. Fokus penelitian ini mengkaji tentang nilai ekonomi dan sosal kain tenun sutera, yaitu dengan melihat dampak sosial keberadaan tenun sutera pada masyarakat Pakkana Kacamatan Tanasitolo Kabupaten Wajo Provinsi Sulawesi Selatan. Adapun yang menjadi sasaran penelitian ini adalah masyarakat dan pemerintah, karena penelitian ini merupakan pendekatan kualitatif, maka dalam menentukan informan dilakukan secara sengaja (Purposive Sampling), Adapun jumlah informan dalam penelitian ini yaitu 20 orang adalah laki-laki 6 (orang), dan perempuan 14 (orang). Instrument penelitian ini adalah peneliti itu sendiri, alat yang digunakan dalam mengumpulkan data yaitu, pedoman wawancara, rekorder, kamera, dan alat penunjang lainnya. Teknik pengumpulan data yaitu observasi, wawancara mendalam, dokumentasi. Teknik analisis data dilakukan melalui reduksi data, penyajian data, verifikasi, sedangkan teknik keabsahan data dilakukan dengan cara uji keabsahan data dalam penelitian kualitatif meliputi Validitas internal, kebergantungan, kepastian.

\section{PEMBAHASAN}

\section{Dampak Nilai Sosial Ekonomi Keberadaan Kain} Sutera Pada Masyarakat

Dampak nilai sosial keberadaan kain tenun bagi masyarakat Pakkana tentunya tidak bisa disanksikan, karena di samping kain tenun digunakan sebagai pakaian sehari-hari kain tenun juga memiliki pengaruh yang dapat di lihat dari sistem adat yang melekat dalam diri mereka. Adapun dampak sosial lain penggunaan sarung sutera dan baju bodo menurut stratifikasi sosial masyarakat dapat dibedakan sebagai berikut:

a. Penggunaan baju bodo. Baju bodo adalah baju adat Bugis-Makassar yang dikenakan oleh perempuan. Sedangkan Lipa' sabbe adalah sarung sutra, biasanya bercorak kotak dan dipakai sebagai bawahan baju bodo. Konon dahulu kala, ada peraturan mengenai pemakaian baju bodo. Masing-masing warna manunjukkan tingkat usia perempuan yang mengenakannya. Sebab baju bodo berbentuk segi empat, biasanya berlengan pendek, yaitu setengah atas bagian siku lengan. Baju bodo juga dikenali sebagai salah satu busana tertua di dunia.

b. Penggunaan sarung sutera. Berdasarkan pandangan melalui penggunaan sarung sutera bagi pemilik kebudayaan Bugis Wajo maka terdapat 4 fungsi sebagai berikut; (1) pakaian semata atau sebagai alat untuk menutup tubuh dalam menahan pengaruh dari alam sekitar, (2) hadiah, (3) simbol status dan gengsi yang dianggap suci, (4) benda yang digunakan dalam upacara adat

Bertahannya budaya penenun pada masyarakat Bugis wajo sampai saat ini tidak terlepas dari kuatnya adat istiadat yang mereka anut sebagai falsafat hidup yang menjembatani kemajuan zaman dan norma-norma adat yang berlaku. Dilihat dari semua aspek kehidupan pada budaya baik sebagai busana, hadiah atau sebagai penghargaan yang tinggi, serta simbol dan pelengkap adat pada upacara budaya setempat. Dampak nilai ekonomi kain tenunan yang digeluti masyarakat Pakkana sampai saat ini tentunya memiliki alasan yang fundamental sehingga keberadaannya sampai saat ini tetap eksis dalam kehidupan masyarakat Pakkana.

Ditinjau pada aspek ekonomis, kegiatan tenun yang dilakukan oleh komunitas penenun di Pakkana ternyata juga menimbulkan pengaruh dalam aspek ekonomi. Penenun tradisional ini guna mendapatkan nilai ekonomis yang lebih tinggi maka mereka menaikkan harga kain tenunannya. Seiring dengan semakin mahalnya harga kain produk industri maka untuk menyesuaikan, komunitas penenun tradisional juga menaikan harga, meskipun nilai ekonomis antara kedua jenis kain tersebut tidak sama. Adapun kenaikan harga kain tenunan ini dapat menambah penghasilan mereka.

Para orang tua di komunitas penenun tradisional ini senantiasa mendorong dan memotivasi anak-anak mereka untuk belajar menenun. Hal ini dilakukan sebagai upaya melanjutkan tardisi dan mewariskannya pada 
generasi selanjutnya Adapun nilal ekonomis yang dimiliki juga diharapkan dapat menarik perhatian para generasi muda di kalangan masyarakat Pakkanna untuk terus belajar menenun dari mereka-mereka yang telah mahir menenun.

Pada saat ini untuk setiap meter kain basil tenunan mereka yaitu kain kapas dapat dihargai sebesar Rp 20.000 sampai pada Rp 35.000 untuk setiap meternya, dan untuk sekali menenun dapat dihasilkan sampai maksimal sepuluh (10) meter kain tenunan, jadi jika dikalikan maka hasilnya bisa mencapai Rp200.000 atau sampai Rp 300.000.

Meskipun bernilai ekonomis, namun aktifitas menenun ini tidak bisa dipandang hanya dari segi ekonomisnya namun harus dipandang dari segi yang, lain. Dari segi sosial budaya bahwa kegiatan menenun ini bukan sekedar pekerjaan yang dapat menghasilkan uang akan tetapi kegiatan menenun merupakan sesuatu yang melekat pada kehidupan komunitas penenun di Pakkana.Menenun merupakan suatu yang tidak terpisahkan dari kehidupan mereka. Komunitas penenun ini mengakui bahwa kegiatan menenun ini tidak sekedar pekerjaan biasa saja akan tetapi suatu kegiatan yang mengasikkan bagi pribadi mereka. Pada saat menenun mulai dari awal sampai pada selesai dan menghasilkan selembar kain tenun maka hal itu dapat membawah suatu rasa kepuasan tersendiri. Alangkah bahagianya dan bangga dengan melihat hasil jerih payahnya, hasil karyanya sendiri.

Harus diakui bahwa pekerjaan menenun ini memang dapat menghasilkan uang. namun bagi segenap orang dalam masyarakat Pakkana bahwa menenun itu adalah suatu kebiasaan yang telah cukup lama melekat dalam kehidupan mereka. Sehingga pada saat ini tidak melakukan kegiatan tersebut terasa ada yang tidak enak, terasa ada yang hilang dalam aktifitasnya seharihari. Hal ini diakui terjadi karena faktor kebiasaan. Menenun secara tradisional mengandung banyak makna bagi komunitas penenun di Pakkana, diantaranya adalah telah menjadi identitas bagi masyarakat di Pakkana. Sebagai contohnya yaitu ketika orang-orang berbicara tentang warga di Pakkana maka pasti akan teringat soal menenun, hal ini karena masyarakat penenun adanya di lingkungan Pakkana.

\section{Komposisi Profesi Serta Kehidupan Masyarakat Pakkana Terhadap Keberadaan Tenun Sutera}

Penduduk yang menekuni kegiatan menenun di Desa Pakk ana berpusat di Dusun Impa-Impa. Dalam bahasa daerah setempat kegiatan menenun disebut dengan nama "Mattennung" Sebagian besar penduduk di Dusun Impa-Impa yaitu khususnya perempuan mahir dalam melakukan praktek menenun yang dikerjakan secara tradisional. jika di daerah ini ketika kita berbicara soal penenun atau dalam bahasa daerah setempat disebut dengan nama "pattennung" maka pasti berkaitan dengan penduduk di lingkungan atau dusun Impa-Impa. Hal ini disebabkan karena orang-orang yang mahir menenun atau komunitas penenun tradisional ini adanya di Dusun Impa-Impa. Berdasarkan data dari Desa Pakkana tahun 2013 penduduk yang mendiami Dusun Impa-Impa sebanyak 1347 jiwa. Berdasarkan dari jenis kelamin yaitu terdiri dari laki-laki sebanyak 627 jiwa dan perempuan sebanyak 720 jiwa. Dari 1347 jiwa jumlah penduduk itu terdapat 33 orang yang masih aktif sebagai penenun yang semuanya berjenis kelamin perempuan, dengan persentase yaitu 2,44\% dari 1347 jiwa dan sebanyak 4,58 \% dari 720 jiwa jumlah penduduk perempuan.

Orang-orang yang dimaksudkan tersebut yang berjumlah 33 orang adalah mereka yang dalam kesehariannya atau hampir setiap hari menjalani rutinitas sebagai seorang penenun. Namun perlu diketahui bahwa sebagian besar dari penduduk perempuan di Desa Impa-Impa secara umum mampu dan mahir dalam menenun tetapi tidak setiap harinya mereka menenun. Akan tetapi mereka juga memiliki tugas sebagai ibu rumah tangga yang membutuhkan libur.

Menyangkut alat-alat untuk menenun, 
pada umumnya mereka masing-masing memiliki yang tersimpan di gudang di rumah mereka masing-masing. Biasanya mereka menenun ketika ada keperluan mendesak untuk menggunakan kain tenun, baik itu untuk keperluan sendiri, untuk keluarga, ataupaun untuk orang lain.

Adapun upaya-upaya atau langkah yang dilakukan dalam beradaptasi ini berkaitan dengan adanya interaksi antara masyarakat penenun dengan lingkungan yang ada disekitarnva. Dalam interaksinya itu akan muncul ide-ide untuk beradaptasi yang berangkat dari sifat memahami kondisi di sekitarnya. Mereka akan berusaha mengidentifikasi dan berusaha selektif terhadap perubahan yang muncul sebagai dampak dari industrialisasi. Tindakan ini kemudian akan disesuaikan dengan tradisi atau kebiasaankebiasaan yang mereka miliki yang akhirnya dapat mempertemukan pada suatu upaya adaptasinya.

\section{KESIMPULAN}

Dampak Keberadaan Kain Sutera Pada Masyarakat Pakkana Kecamatan Tanasitolo Kabupaten Wajo adalah (1) Dampak nilai sosial; merupakan keberadaan kain tenun bagi masyarakat Pakkana sebagai pakaian sehari-hari kain tenun juga memiliki pengaruh yang dapat dilihat dari sistem adat yang melekat dalam diri mereka. Menunjukkan arti simbolis dan identitas tersendiri. (2) Dampak nilai ekonomi; kegiatan tenun yang dilakukan oleh komunitas penenun di Pakkanna mendapatkan nilai ekonomis yang lebih. Adapun kenaikan harga kain tenunan ini dapat menambah penghasilan mereka.

\section{DAFTAR PUSTAKA}

[1] Abdul Kahar Wahid, (1988). Ragam Hias Sulawesi Selatan dan Pengembangannya. Disampaikan dalam Ceramah pembukaan Pameran Khusus Ragam Hias Tradisional Sulawesi Selatan di Museum Negeri Makassar: PT Rayhan Intermedia Rayhan Intermedia Galigo.

[2] Anonim, (2012). Kabupaten Wajo dalam Angka 2012. Sengkang: Agung

[3] Firman, M. (2009). Strategi Adaptasi Komunitas Penenun Dalam Menghadapi Indutrialisasi (Kasus di Kelurahan Lewaja Kecamatan Enrekang Kabupaten Enrekang). Skripsi. Tidak diterbitkan. Makassar. Fakultas IImu Sosial Universitas Negeri Makassar.

[4] Johnson, Paul, D. (1986). Teori Sosiologi Klasik dan Modern. Jakarta: PT Gramedia.

[5] Rahim, Rahman. (2011). Nilai-Nilai Utama Kebudayaan Bugis. Yogyakarta: PT Ombak.

[6] Ritzer, George. (2011). Sosiologi Ilmu Pengetahuan Berparadigma Ganda. Jakarta: PT Rajagrafindo Persada.

[7] Rahim, Rahman. (2011). Nilai-Nilai Utama Kebudayaan Bugis. Yogyakarta: Ombak.

[8] Rahardjo. (1999). Pengantar Sosiologi Pedesaan Dan Pertanian. PT. Gadjah university press.

[9] Rukmini, (1979). Tenun Tradisional Bugis Makasar. Sulawesi Selatan: Proyek Pembinaan Permuseuman.

[10] Sahriah. (1993). Tenunan Khas Sulawesi Selatan Dan Tenggara :Proyek Pembinaan Permuseuman Sulawesi Selatan Bekerja Sama Proyek Pembinaan Permuseuman Selawesi Tenggara.

[11] Sahriah dkk. (1990). Ragam Hias Tenunan Nusantara. Sulawesi Selatan: Proyek Pembinaan Permuseuman

[12] Sanderson, Stephen. (2011). Makrososiologi Sebuah Pendekatan Terhadap Realitas Sosiologi. PT. Rajawali Pers: Jakarta.

[13] Sekanto, Soerjono. (2012). Sosiologi suatu pengantar. PT. Raja Grafindo Persada. Jakarta.

[14] Wahyuni, E.D.A. (2013). Motif Lipa Sabbe (Sarung Sutera) Sengkang Kabupaten Wajo Provinsi Sulawesi Selatan Tahun 2013. Skripsi. Tidak Diterbitkan. Universitas Negeri Surabaya. 